\title{
Pengaruh Persentase Carboxy Methyl Cellulose serta Imbangan Sari Buah Naga Merah dan Pisang Ambon terhadap Karakteristik Fisikokimia Yogurt Aneka Buah
}

\section{Effect of Carboxy Methyl Cellulose Percentage and Ratio of Red Dragon and Ambon Banana Juice to Physicochemical Characteristics on Mixed Fruit Yogurt}

\author{
S. R. Zulaikhah ${ }^{1 *}$, \& I. Sulistiyawati ${ }^{2}$ \\ ${ }^{1}$ Program Studi Peternakan, Fakultas Sains dan Teknologi, Universitas Nahdlatul Ulama Purwokerto \\ 2 Program Studi Biologi, Fakultas Sains dan Teknologi, Universitas Nahdlatul Ulama Purwokerto \\ Jalan Sultan Agung No. 42, Karangklesem, Purwokerto \\ *Email korespondensi: rahmawatidjunaidi0@gmail.com
}

- Diterima: 28 Juli 2021 • Direvisi: 27 Agustus 2021 • Disetujui: 30 Agustus 2021

\begin{abstract}
ABSTRAK. Penelitian ini bertujuan untuk mengetahui pengaruh persentase Carboxy Methyl Cellulose (CMC) dan imbangan sari buah naga merah dan pisang ambon yang digunakan serta interaksinya terhadap $\mathrm{pH}$, total asam dan viskositas mixed fruit yogurt yang dihasilkan. Penelitian ini menggunakan Rancangan Acak Kelompok Pola Faktorial (RAK) dengan faktor pertama adalah persentase CMC $(0 \%, 0,5 \%, 1 \%$ dan 1,5\% b/v), faktor kedua adalah imbangan sari buah naga merah dan pisang ambon (25:75; 50:50; dan 75:25), dengan ulangan sebanyak 3 kali. Kesimpulan dari hasil penelitian ini adalah faktor penambahan CMC memberikan pengaruh menaikkan nilai $\mathrm{pH}$ dan viskositas mixed fruit yogurt yang dihasilkan, nilai $\mathrm{pH}$ berkisar antara 4,15-4,29 dan viskositas 1308,69-3975,82 mPa.s. Faktor imbangan sari buah memberikan pengaruh terhadap total asam yogurt, dengan nilai berkisar antara 1,09-0,91 \%. Faktor interaksi antara CMC dan persentase sari buah yang digunakan tidak memberikan pengaruh terhadap nilai $\mathrm{pH}$, total asam dan viskositas mixed fruit yogurt yang dihasilkan.
\end{abstract}

Kata kunci: Mixed fruit yogurt, buah naga merah, pisang ambon, CMC, fisikokimia.

ABSTRACT. This study aims to determine the effect of increasing Carboxy Methyl Cellulose (CMC) percentages and ratio of red dragon fruit juice and banana ambon used as well as its interaction to $\mathrm{pH}$, total acid and viscosity of mixed fruit yogurt produced. This study used a Completely Randomized Block Design (CRBD) factorial Pattern with the first factor was several the percentages of CMC $(0 \%, 0.5 \%, 1 \%$ and $1.5 \%(w / v)$, the second factor was the ratio of red dragon fruit juice and banana ambon (25:75; 50:50; and 75:25), then repeated treatment 3 times. The conclusion of the results of this study is the added factor of CMC has an effect on increasing the value of $\mathrm{pH}$ and viscosity of mixed fruit yogurt produced, $\mathrm{pH}$ values range from 4.15-4.29 and viscosity 1308.69-3975.82 $\mathrm{mPa.s}$. . The ratio of juices have an effect on the total acid of yogurt, with values ranging from $1.09-0.91 \%$. . The interaction factor between CMC and the ratio of juice have no effect on the $\mathrm{pH}$ value, total acid and viscosity of mixed fruit yogurt produced.

Keywords: Mixed fruit yogurt, red dragon fruit, pisang ambon, CMC, physicochemistry.

\section{PENDAHULUAN}

Olahan susu fermentasi dengan bantuan bakteri asam laktat Streptococcus thermophillus dan Lactobacillus bulgaricus, kita kenal dengan sebutan yogurt. Yogurt dapat ditingkatkan nilai fungsionalnya dengan menggunakan probiotik Lactobacillus acidophillus maupun dari golongan Bifidobacterium. Dalam meningkatkan kualitas dan daya tarik konsumen akan yogurt ini, maka dilakukan inovasi penambahan buahbuahan dalam prosesing yogurt. Penggunaan buah yang naga merah dan pisang ambon menjadi alternatif dalam penganekaragaman olahan yogurt dan menjadi salah satu pangan fungsional dari susu.

Buah naga merah memiliki aktivitas antioksidan sebesar 67,45 ppm (Widianingsih, 
2015) dan mengandung antosianin sebesar 8,8 $\mathrm{mg} / 100 \mathrm{~g}$ dari daging buahnya (Priska et al., 2018). Kandungan nutrisi yang tinggi ini diharapkan yogurt yang dihasilkan mempunyai nilai nutrisi yang tinggi pula dan mempunyai tingkat kesukaan konsumen yang tinggi pula karena warna yang dihasilkan.

Penggunaan pisang ambon selain ketersediaan yang melimpah di Indonesia, banyak manfaat yang diperoleh dari buah tersebut. Azzahra, dan Nisa (2016) menyatakan pisang Ambon selain rasanya enak dan mudah diperoleh, juga memiliki kalori yang cukup tinggi yaitu $99 \mathrm{kkal} / 100$ g. Pisang juga kaya akan vitamin B, C, kalsium, asam folat, zat besi, fosfor, niasin, dan kalium. Selain kandungan gizi, pisang ambon juga memiliki beberapa manfaat kesehatan, antara lain: meningkatkan sistem kekebalan tubuh, mengurangi gangguan pencernaan, menurunkan resiko kencing manis dan hiperlipidemia.

Penggunaan campuran buah antara buah naga merah dan pisang ambon dalam penelitian ini dimaksudkan untuk mendapatkan yogurt yang menarik perhatian konsumen dari sisi warna oleh buah naga merah dan aroma serta rasa enak dari pisang ambon, selain kandungan nutrisi yang bagus pada kedua buah tersebut.

Salah satu kekurangan dalam proses pembuatan yogurt adalah terjadinya pemisahan antara padatan dan cairan, yang dikenal dengan istilah sineresis. Hal ini terjadi karena penurunan daya ikat air (whey off), ini disebabkan oleh $\mathrm{pH}$ yogurt berada di kisaran titik isoelektrik casein. Gel casein yang terletak di lingkungan $\mathrm{pH}$ isoelektrik memiliki kekuatan pengikatan molekul air yang relatif lemah, mendorong pelepasan molekul air pada permukaan gel atau sintesis dan penurunan viskositas (Krisnaningsih et al., 2020). Efek dari sineresis ini dapat mempengaruhi kualitas yogurt dan penerimaan konsumen. Untuk itu perlu dilakukan penambahan bahan penstabil, sebagaimana pendapat Tamine dan Robinson
(2000) menyatakan bahwa tujuan utama menambahkan bahan stabilisasi ke yogurt adalah untuk meningkatkan dan mempertahankan sifat khas yogurt yang diinginkan, seperti viskositas, konsistensi, penampilan dan rasa yang khas. Dua peran utama bahan penstabil yaitu sebagai pengikat air dan meningkatkan viskositas yogurt.

Berdasarkan penelitian kami sebelumnya, yogurt buah naga merah memiliki viskositas semakin menurun dan meningkatnya sineresis apabila level buah naga merah dinaikkan sampai 6\% (Zulaikhah, 2021). Begitu pula pada yogurt pisang ambon pada Zulaikhah dan Fitria (2020) menunjukkan viskositas yang rendah dengan penambahan pisang ambon sampai $6 \%$. Kelemahan ini mendukung penulis untuk menggunakan bahan penstabil dalam penelitian ini.

Bahan penstabil yang dapat digunakan dalam produk yogurt adalah CMC (Carboxy Methyl Cellulose). CMC cocok digunakan dalam yogurt karena tidak berbau, meningkatkan viskositas, larut dalam air dingin atau air panas bahkan lebih larut dalam campuran etanol atau air dan alkohol 50\%, dan dapat stabil pada $\mathrm{pH}$ 3-7 (Imeson, 2010).

Berdasarkan kajian di atas, telah dilakukan penelitian yang bertujuan untuk melihat pengaruh penambahan level CMC dan imbangan sari buah yang digunakan serta interaksinya terhadap $\mathrm{pH}$, total asam dan viskositas yogurt yang dihasilkan.

\section{MATERI DAN METODE}

Penelitian dilaksanakan di Laboratorium Teknologi Hasil Ternak Fakultas Peternakan Universitas Jenderal Soedirman, Purwokerto. Rancangan penelitian dalam pengambilan data dengan menggunakan Rancangan Acak Kelompok pola faktorial. Faktor pertama adalah persentase CMC $(0 \%, 0,5 \%, 1 \%$ dan $1,5 \%)(\mathrm{b} / \mathrm{v})$, faktor kedua adalah imbangan sari buah naga merah: pisang ambon (25:75; 50:50; 
dan 75:25), dan dilakukan dalam 3 blok sebagai ulangan. Total sari buah yang ditambahkan adalah $12 \%$. Data nilai $\mathrm{pH}$, total asam dan viskositas dilakukan analisa variansi dan diuji lanjut dengan uji wilayah Duncan.

Gambaran perlakuan dalam penelitian adalah sebagai berikut:

$\mathrm{C} 1=$ Faktor penambahan $\mathrm{CMC} 0 \%$

$\mathrm{C} 2=$ Faktor penambahan $\mathrm{CMC} 0,5 \%$

$\mathrm{C} 3=$ Faktor penambahan CMC $1 \%$

$\mathrm{C} 4=$ Faktor penambahan $\mathrm{CMC} 1,5 \%$

P1 = imbangan buah naga merah : buah pisang ambon $(25: 75)$

P2 = imbangan buah naga merah : buah pisang ambon $(50: 50)$

P3 = imbangan buah naga merah : buah pisang ambon $(75: 25)$

Penelitian ini dilakukan mulai dari pembuatan sari buah naga merah, sari buah pisang, pembuatan kultur kerja, pembuatan mixed fruit yogurt. Jenis pisang yang digunakan adalah pisang Ambon. Starter yang digunakan adalah starter konvensional "Yogourmet" dengan kandungan tiga bakteri asam laktat (Lactobacillus bulgaricus, Streptococcus thermophillus dan Lactobacillus acidophilus), yang diperoleh dari toko online.

\section{Pembuatan Kultur Kerja Yogurt}

Pembuatan kultur kerja yogurt ini mengacu pada cara kerja Zulaikhah dan Fitria
(2020), yaitu bubuk yogurt konvensional terdiri dari campuran bakteri $S$. thermophillus, $L$. bulgaricus dan L. acidoplhillus sebanyak $5 \mathrm{~g}$ dimasukkan ke dalam $1000 \mathrm{ml}$ susu fullcream yang telah dipasteurisasi pada suhu $75^{\circ} \mathrm{C}$ selama 15 detik kemudian diinkubasi pada suhu $42^{\circ} \mathrm{C}$ selama 6 jam. Setelah itu kultur ini diambil sebanyak 5\% dimasukkan ke dalam susu fullcream dan diinkubasikan selama kurang lebih 4 jam pada suhu $42^{\circ} \mathrm{C}$, setelah itu disimpan dalam suhu refrigerator dan digunakan sebagai kultur kerja.

\section{Pembuatan Sari Buah Pisang Ambon}

Mengacu pada Zulaikhah dan Fitria (2020) Pisang Ambon sudah matang sepenuhnya dicuci, dikupas dan dipotong hingga ukuran $0,5-2 \mathrm{~cm}$, kemudian dipasteurisasi $88^{\circ} \mathrm{C}$ selama 15 detik kemudian dihancurkan dengan blender waring dan ditambah dengan vitamin $C$, maka akan diperoleh pure pisang atau jus pisang.

\section{Pembuatan Sari Buah Naga Merah}

Mengacu pada Zulaikhah (2021) Daging buah naga merah dihancurkan dengan blender kecepatan satu selama 10 detik sehingga bubur buah naga merah diperoleh. Bubur buah disaring dan dilakukan pasteurisasi pada $88^{\circ} \mathrm{C}$ 15 detik sehingga jus siap digunakan.

\section{Pembuatan Mixed Fruit Yogurt}

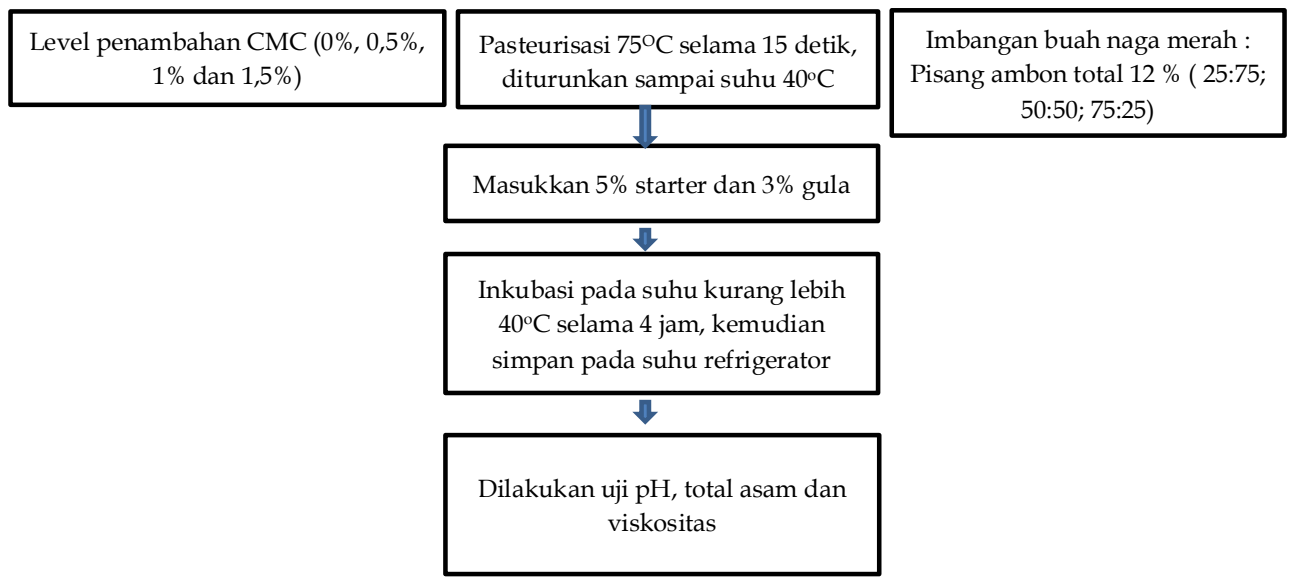

Gambar 1. Pembuatan Mixed Fruit Yogurt. 


\section{Uji pH}

Uji pH yogurt dilakukan dengan menggunakan $\mathrm{pH}$ meter elektrik, yang sudah dikalibrasi sebelumnya pada $\mathrm{pH} 4$ dan 7 . Alat dimasukkan ke dalam yogurt dan dilakukan pembacaan hasil.

\section{Uji Total Asam}

Uji total asam pada yogurt dilakukan dengan metode titrasi sesuai metode Hadiwiyoto (1994). Analisis total asam pada yogurt dilakukan seperti analisis pada susu. Menimbang sampel yogurt $5 \mathrm{ml}$ dan menambahkan aquades $10 \mathrm{ml}$ dalam Erlenmeyer, kemudian menambahkan 2-3 tetes indikator PP 1\%, menggunakan pipet $1 \mathrm{ml}$. Alat titrasi menggunakan buret yang diisi dengan larutan 0,1 N NaOH menggunakan gelas ukur dan miniskus permulaan kemudian dibaca. Yogurt dititrasi sampai warna susu berubah menjadi merah muda selama minimal 30 detik. Tingkat keasaman dapat dihitung dengan rumus sebagai berikut: $=\underline{m l ~ N a O H} \times 0,009 \times 100 \%$

berat sampel dalam gr

\section{Uji Viskositas}

Viskositas yogurt diukur dengan menggunakan viscometer. Sama seperti pada Zulaikhah (2021), viskometer yang digunakan adalah Digital Viscometer NDJ-5S. Cara pengujian viskositas dengan menyalakan alat dan sampel ditempatkan pada tempatnya kemudian melakukan pengukuran. Hasil nilai viskositas bisa langsung dibaca pada alat tersebut, dengan satuan mPa.s.

\section{HASIL DAN PEMBAHASAN}

\section{$\mathrm{pH}$}

Hasil pengukuran dan analisis variansi data $\mathrm{pH}$ mixed fruit yogurt dengan perlakuan level penambahan CMC dan imbangan buah dapat dilihat di Tabel 1.

Tabel 1. Hasil Analisis Variansi pH Mixed Fruit Yogurt

\begin{tabular}{lllll}
\hline Perlakuan & \multicolumn{3}{c}{ Imbangan sari buah naga merah:pisang ambon } & \multirow{2}{*}{ Rerata } \\
\cline { 2 - 4 } Konsentrasi penstabil & P1(25:75) & P2(50:50) & P3 (75:25) & \\
\hline C1 (0\%) & $4,20 \pm 0,04$ & $4,13 \pm 0,10$ & $4,11 \pm 0,02$ & $4,15 \pm 0,067 \mathrm{~b}$ \\
C2 (0,5\%) & $4,18 \pm 0,08$ & $4,17 \pm 0,08$ & $4,19 \pm 0,07$ & $4,18 \pm 0,065 \mathrm{~b}$ \\
C3 $(1 \%)$ & $4,20 \pm 0,09$ & $4,19 \pm 0,08$ & $4,19 \pm 0,06$ & $4,19 \pm 0,064 \mathrm{~b}$ \\
C4 (1,5\%) & $4,25 \pm 0,09$ & $4,29 \pm 0,14$ & $4,32 \pm 0,13$ & $4,29 \pm 0,110 \mathrm{a}$ \\
Rerata & $4,20 \pm 0,070$ & $4,19 \pm 0,105$ & $4,20 \pm 0,104$ & \\
\hline
\end{tabular}

Keterangan: Angka yang diikuti huruf yang sama tidak berbeda nyata pada DMRT 5\%.

Berdasarkan hasil analisis variansi dan uji lanjut DMRT terhadap variabel $\mathrm{pH}$ mix yogurt fruit, dapat dilihat bahwasanya faktor perlakuan CMC memberikan pengaruh yang nyata $(\mathrm{P}<0,05)$ terhadap $\mathrm{pH}$ mixed fruit yogurt, faktor persentase buah tidak memberikan pengaruh yang nyata $(\mathrm{P}>0,05)$ terhadap $\mathrm{pH}$ mixed fruit yogurt dan tidak terjadi interaksi antara kedua faktor perlakuan $(\mathrm{P}>0,05)$ terhadap variabel $\mathrm{pH}$ mixed fruit yogurt.

Faktor imbangan sari buah naga merah dan pisang ambon tidak mempengaruhi $\mathrm{pH}$ akhir yogurt $(\mathrm{P}>0,05)$ kemungkinan disebabkan $\mathrm{pH}$ awal keduanya saat ditambahkan relatif tidak jauh berbeda. Saat penelitian $\mathrm{pH}$ awal sari buah naga merah dicatat sebesar 4,76 dan $\mathrm{pH}$ pisang ambon adalah 4,84 .

Faktor CMC sangat mempengaruhi $\mathrm{pH}$ yogurt terutama pada level 1,5\% dihasilkan $\mathrm{pH}$ sebesar 4,286, level penambahan dari $0 \%, 0,5 \%$ dan $1 \%$ tidak memberikan perbedaan terhadap $\mathrm{pH}$ yang dihasilkan, walaupun bila dilihat terjadi peningkatan. Peningkatan $\mathrm{pH}$ karena faktor penambahan $\mathrm{CMC}$ ini kemungkinan 
dikarenakan CMC mempunyai sifat menyerap air sehingga ketersediaan air sebagai media pertumbuhan bakteri asam laktat akan berkurang dan proses pengedaran nutrisi yang ditunjang oleh aktifitas air secara difusi dan enzimatik akan menurun, kondisi ini berakibat bakteri asam laktat akan mengalami mal nutrisi dan energi untuk memfermentasikan laktosa menjadi asam laktat. Hal ini sejalan dengan penelitian Djali et. al (2018) yang menghasilkan nilai $\mathrm{pH}$ yogurt mengalami peningkatan setelah digunakannya stabilizer, gum xanthan. Dalam penelitian tersebut dihasilkan kecenderungan produksi asam yang lebih lambat karena media yang lebih kental berakibat menurunnya kerja mikroorganisme dalam mengubah laktosa.

\section{Total Asam}

Hasil pengukuran dan analisis variansi data total asam mix fruit yogurt dengan perlakuan level penambahan CMC dan persentase imbangan buah naga merah dan pisang ambon dapat dilihat di Tabel 2.

Tabel 2. Hasil Analisis Variansi Total Asam Mixed Fruit Yogurt (\%)

\begin{tabular}{|c|c|c|c|c|}
\hline \multirow{2}{*}{$\begin{array}{l}\text { Perlakuan } \\
\text { Konsentrasi penstabil }\end{array}$} & \multicolumn{3}{|c|}{ Imbangan sari buah naga merah : pisang ambon } & \multirow{2}{*}{ Rerata } \\
\hline & P1(25:75) & $\mathrm{P} 2(50: 50)$ & P3 (75:25) & \\
\hline $\mathrm{C} 1$ & $1,13 \pm 0,11$ & $0,98 \pm 0,10$ & $0,92 \pm 0,06$ & $1,01 \pm 0,12$ \\
\hline $\mathrm{C} 2$ & $1,11 \pm 0,11$ & $0,92 \pm 0,14$ & $0,91 \pm 0,05$ & $0,98 \pm 0,13$ \\
\hline $\mathrm{C} 3$ & $1,08 \pm 0,15$ & $0,91 \pm 0,08$ & $0,91 \pm 0,04$ & $0,97 \pm 0,12$ \\
\hline $\mathrm{C} 4$ & $1,06 \pm 0,13$ & $0,89 \pm 0,08$ & $0,90 \pm 0,03$ & $0,95 \pm 0,11$ \\
\hline Rerata & $1,10 \pm 0,11 \mathrm{a}$ & $0,92 \pm 0,09 \mathrm{~b}$ & $0,91 \pm 0,04 \mathrm{~b}$ & \\
\hline
\end{tabular}

Keterangan: Angka yang diikuti huruf yang sama tidak berbeda nyata pada DMRT 5\%.

Berdasarkan hasil analisis variansi dan dilakukan uji lanjut DMRT diperoleh bahwa faktor imbangan buah naga merah : buah pisang memberikan pengaruh yang nyata $(\mathrm{P}<0,05)$ terhadap total asam mixed fruit yogurt. Namun hasil anova menunjukkan faktor CMC tidak memberikan pengaruh yang nyata $(\mathrm{P}>0,05)$ terhadap nilai total asam yogurt yang dihasilkan, dan tidak ada interaksi antara faktor CMC dengan imbangan buah naga merah: buah pisang ambon terhadap nilai total asam mixed fruit yogurt $(\mathrm{P}>0,05)$.

Total asam mixed fruit yogurt pada penelitian ini masih dalam rentang total asam yogurt yang direkomendasikan oleh SNI (2009) yang harusnya $0,5-2,0 \%$, dalam penelitian ini berkisar antara $0,89-1,13 \%$.

Total asam yang dihasilkan pada mixed fruit yogurt ini menunjukkan hasil kerja dari bakteri asam laktat yang dipengaruhi oleh imbangan buah naga merah dan buah pisang ambon sebagai prebiotik untuk media bakteri asam laktat starter yogurt. Semakin tinggi buah naga merah maka akan dihasilkan total asam yang semakin sedikit, atau sebaliknya total asam yang tinggi karena penggunaan buah pisang yang tinggi pula. Mixed fruit yogurt ini diperoleh nilai total asam tertinggi dengan imbangan buah naga merah : buah pisang ambon (25: 75) atau P1, yaitu sebesar 1,10\%. Hal ini kemungkinan karena buah pisang ambon mempunyai sifat prebiotik yang kaya akan inulin dan fruktooligosakarida, sehingga semakin tinggi imbangan pisang yang digunakan maka ketersediaan karbohidrat dalam yogurt semakin tinggi, maka bakteri asam laktat akan mengubah menjadi asamasam organik juga semakin tinggi. Hal ini sejalan dengan pendapat Handayani dan Aini (2019) yang menyatakan bahwa pisang adalah bahan pangan yang mengandung karbohidrat baik dalam bentuk glukosa, dan fruktosa yang akan dihidrolisis menghasilkan asam-asam organik. Yogurt yang ditambah dengan tepung pisang akan mengandung karbohidrat yang tinggi, sehingga jumlah asam-asam organik 
yang dihasilkan dari metabolisme karbohidrat juga tinggi.

Dalam penelitian ini terjadi hubungan yang sinergis antara nilai total asam dan $\mathrm{pH}$. Semakin tinggi total asam maka $\mathrm{pH}$ yang dihasilkan juga semakin rendah, hal ini dikarenakan terjadi perubahan dalam jumlah ion $\mathrm{H}^{+}$. Penurunan nilai $\mathrm{pH}$ yogurt terjadi karena peningkatan jumlah ion $\mathrm{H}^{+}$sehingga memicu peningkatan jumlah asam.
Viskositas menurut Zulaikhah dan Fitria (2020) adalah kekentalan pada produk pangan. Viskositas yogurt mengilustrasikan sifat cairan yang menentang aliran yang dapat memberikan peningkatan energi yang dapat menahan gerakan relatif.

Hasil pengukuran dan analisis variansi data viskositas fruit yogurt dengan perlakuan level penambahan CMC dan persentase imbangan buah naga merah dan pisang ambon dapat dilihat di Tabel 3.

\section{Viskositas}

Tabel 3. Hasil Analisis Variansi Viskositas Mixed Fruit Yogurt (mPa.s)

\begin{tabular}{lllll}
\hline Perlakuan & \multicolumn{3}{l}{ Imbangan sari buah naga merah : pisang ambon } & \multirow{2}{*}{ Rerata } \\
\cline { 2 - 4 } Konsentrasi penstabil & P1(25:75) & P2(50:50) & P3 (75:25) & \\
\hline C1 & $1444,73 \pm 236,83$ & $1375,50 \pm 266,41$ & $1105,83 \pm 281,39$ & $1308,69 \pm 274,97 \mathrm{c}$ \\
C2 & $2672,83 \pm 259,62$ & $3125,97 \pm 738,50$ & $2373,67 \pm 544,72$ & $2724,16 \pm 631,85 \mathrm{~b}$ \\
C3 & $3974,80 \pm 1,06$ & $3973,60 \pm 1,40$ & $3606,10 \pm 637,13$ & $3851,50 \pm 367,91 \mathrm{a}$ \\
C4 & $3976,33 \pm 1,89$ & $3975,901,25$ & $3975,23 \pm 0,47$ & $3975,82 \pm 1,25 \mathrm{a}$ \\
Rerata & $3017,18 \pm 1129,99$ & $3112,74 \pm 1157,80$ & $2765,21 \pm 1235,75$ & \\
\hline
\end{tabular}

Keterangan: Angka yang diikuti huruf yang sama tidak berbeda nyata pada DMRT 5\%.

Hasil analisis variansi dan uji lanjut DMRT menunjukkan bahwa viskositas nyata dipengaruhi oleh faktor penambahan CMC $(\mathrm{P}<0,05)$. Faktor imbangan buah naga merah : pisang ambon yang digunakan tidak memberikan pengaruh nyata $(\mathrm{P}>0,05)$ pada viskositas mixed fruit yogurt. Tidak terjadi interaksi antara faktor penambahan CMC dengan imbangan buah $(\mathrm{P}>0,05)$ terhadap variabel viskositas pada mixed fruit yogurt.

Berdasarkan Tabel di atas terlihat bahwa viskositas pada penambahan CMC yang semakin tinggi akan diperoleh viskositas yang semakin tinggi pula, dimana $\mathrm{C} 1(=\mathrm{CMC} 0 \%)$ berbeda nyata dengan $\mathrm{C} 2(=\mathrm{CMC} 0,5 \%), \mathrm{C} 3$ $(\mathrm{CMC}=1 \%)$ dan $\mathrm{C} 4$ (CMC 1,5\%), sedangkan C3 dan C4 tidak berbeda nyata viskositasnya, namun dilihat dari reratanya tetap mengalami peningkatan. Hal ini disebabkan karena kerja CMC yang dapat mengikat air dan protein, protein dalam yogurt yang dimaksud adalah kasein yang ada pada susu yang banyak mengandung asam amino. Menurut Wuestenberg (2015) menyatakan bahwa Asam amino memiliki gugus elektron (-NH2) mendapat proton dari oksonium misalnya oksigen yang memiliki 3 proton $(\mathrm{H} 3 \mathrm{O}+)$ menghasilkan asam amino memiliki gugus positif $(-\mathrm{NH} 3+)$. Antara ikatan kation protein $(-\mathrm{NH} 3+)$ dan daya elektrostatik anion CMC (-COO-) membawa pengaruh gaya tarik menarik. Adanya gaya antara protein dan CMC ini dapat meningkatkan kekentalan yogurt.

Penelitian penggunaan stabilizer yang semakin tinggi dalam prosessing yogurt akan menghasilkan viskositas yang semakin tinggi ini juga terjadi pada penelitian Krisnaningsih et al. (2020) yang menggunakan umbi talas sebagai sumber stabilizer. Hal ini selain stabilizer mengikat protein, stabilizer terdapat amilosa dan amilopektin yang mampu mengikat air dalam yogurt sehingga viskositas yogurt semakin tinggi.

Berdasarkan hasil penelitian ini, penulis merekomendasikan untuk membuat yogurt dengan total asam yang tinggi $(1,10 \%)$ dan viskositas yang sudah baik $(3017,18 \mathrm{mPa} . \mathrm{s})$ 
Pengaruh Persentase Carboxy Methyl Cellulose serta Imbangan Sari Buah Naga Merah dan Pisang Ambon terhadap Karakteristik

adalah menggunakan imbangan sari buah naga merah dan pisang ambon sebesar 25:75 (P1). Penambahan level CMC yang terbaik dalah $\mathrm{C} 4$ (CMC 1,5\%), karena menghasilkan yogurt dengan yang tertinggi nilai $\mathrm{pH}(4,286)$ dan viskositasnya (3975,82 $\mathrm{mPa} . \mathrm{s})$.

\section{KESIMPULAN}

Hasil penelitian menunjukkan bahwa faktor imbangan sari buah memberikan pengaruh terhadap total asam yogurt, dengan nilai berkisar antara 1,10 - 0,91 \%. Faktor penambahan $\mathrm{CMC}$ memberikan pengaruh menaikkan nilai $\mathrm{pH}$ dan viskositas mixed fruit yogurt yang dihasilkan, nilai $\mathrm{pH}$ berkisar antara 4,15-4,29 dan viskositas 1308,69-3975,82 mPa.s. Faktor interaksi antara CMC dan persentase sari buah yang digunakan tidak memberikan pengaruh terhadap nilai $\mathrm{pH}$, total asam dan viskositas mixed fruit yogurt yang dihasilkan.

\section{KONFLIK KEPENTINGAN}

Naskah artikel ini ditulis dengan bebas dan tidak memiliki konflik kepentingan yang berhubungan dengan keuangan, pribadi atau organisasi.

\section{UCAPAN TERIMA KASIH}

Peneliti mengucapkan terima kasih kepada LPPM UNU Purwokerto atas semua support dan bantuannya, dan Direktorat Riset dan Pengabdian Masyarakat (DRPM) Kementerian Pendidikan, Kebudayaan, Riset dan Teknologi atas bantuan finansialnya dalam program penelitian dengan skema Penelitian Dosen Pemula (PDP) tahun anggaran 2020/2021.

\section{DAFTAR PUSTAKA}

Azzahra, F., dan C. Nisa. 2016. Karakteristik Mutu dan Sensorik Pangan Fungsional: Stirred Yoghurt Tersubstitusi Madu dan Pure Pisang Ambon (Musa paradisiaca) dengan
Menggunakan Inokulum Lactobacillus rhamnosus. Artikel Penelitian. http://eprints.undip.ac.id/62132/1/905_FAT IH_AZZAHRA.pdf

Djali, M., S. Huda, dan L. Andriani, 2018. Karakteristik Fisikokimia Yogurt Tanpa Lemak dengan Penambahan Whey Protein Concentrate dan Gum Xanthan. Agritech, 38 (2): 178-186.

DOI: http://doi.org/10.22146/agritech.22451.

Hadiwiyoto, S., 1994. Teori dan Prosedur Pengujian Mutu Susu dan Hasil Olahannya. Liberty, Yogyakarta.

Handayani, I. dan N. Aini, 2019. Karakteristik Sensori Yogurt yang Dibuat dengan Penambahan Lactobacillus casei dan Tepung Pisang Ambon. Prosiding Seminar Nasional dan Call for Papers "Pengembangan Sumber Daya Perdesaan dan Kearifan Lokal Berkelanjutan IX" 19- 20 November 2019 Purwokerto.

Imeson, A., 2010. Food Stabilisers,Thickeners and Gelling Agents. Inggris: Blackwell Publishing.

Krisnaningsih, A. T. J., T. I. W. Kustyorini, dan M. Meo. 2020. Pengaruh Penambahan Pati Talas (Colocasia esculenta) sebagai Stabilizer terhadap Viskositas dan Uji Organoleptik Yogurt. Jurnal Sains Peternakan. 8(1): 66-76.

Ningsih, E.L., I. L. Kayaputri, dan I. S. Setiasih, 2019. Pengaruh Penambahan (Carboxy Methyl Cellulose) Terhadap Karakteristik Fisik Yogurt Probiotik Potongan Buah Naga Merah. Jurnal Ilmu dan Teknologi Hasil Ternak, 14(10): 60-69.

https://doi.org/0.21776/ub.jitek.2019.014.01.7

Priska, M., N. Peni, L. Carvallo, dan Y. D. Ngapa, 2018. Review: Antosianin dan Pemanfaatannya. Cakra Kimia (Indonesian EJournal of Applied Chemistry), 6(2): 79-97.

Standar Nasional Indonesia, 2009. Yogurt. SNI 2981: 2009.

Tamine, A. Y., dan R. K. Robinson, 2000. Yogurt Science and Teknology. Second Edition. Woodhead Publishing Limited, England.

Widianingsih, M., 2015. Aktivitas Antioksidan Ekstrak Metanol Buah Naga Merah 
(Hylocereus polyrhizus (F.A.C Weber) Britton \& Rose) Hasil Maserasi dan Dipekatkan dengan Kering Angin. Jurnal Wiyata, 3(2): 146-150.

Wustenberg, T., 2015. Cellulose and Cellulose Devirates in the Food Industry. Jerman: Wiley-VCH.

Zulaikhah, S.R., 2021. Sifat Fisikokimia Yogurt dengan Berbagai Proporsi Penambahan Sari
Buah Naga Merah (Hylocereus polyrhizus). Jurnal Sains Peternakan, 9(1): 7-15.

Zulaikhah, S.R. dan R. Fitria (2020). Total Asam, Viskositas dan Kesukaan Yogurt Buah Pisang Ambon (Musa paradisiaca). Jurnal Sains Peternakan, 8(2): 77-83. 